\title{
Effect of nitrogen sources on fruit characteristics and seed physiological quality of Physalis angulata L. ${ }^{1}$
}

\author{
Tamara Torres Tanan ${ }^{2}$, Alismário Leite da Silva², \\ Uasley Caldas de Oliveira ${ }^{3}$, Lourival Palmeira Gonçalves Neto ${ }^{2}$, Marilza Neves do Nascimento ${ }^{2}$
}

\section{ABSTRACT}

Choosing an appropriate nitrogen source is of utmost importance, since it affects the plant development and fruit and seed yield. This study aimed to evaluate the quality of Physalis angulata fruits and seeds obtained from plants grown in a hydroponic system, under different concentrations of nitrate and ammonium. The treatments consisted of four $\mathrm{NO}_{3}^{-}: \mathrm{NH}_{4}^{+}$ ratios $(100: 0,75: 25,50: 50$ and 25:75). After full grown, the fruits were collected for biometric and chemical analyses, and seeds were removed for the germination test. The germination test was conducted in a germination chamber and the parameters evaluated were the germination rate, mean germination time, speed, germination uniformity coefficient and relative frequency. Fruits with lower weight and diameter were obtained at doses above $50 \%$ of ammonium; however, there was an increase for ${ }^{\circ}$ Brix and soluble solids/titratable acidity ratio. Such dosage also reduced the rate, speed and uniformity of germination. The combined use of nitrogen sources $\left(50: 50\right.$ of $\left.\mathrm{NO}_{3}^{-}: \mathrm{NH}_{4}^{+}\right)$ is recommended, because it produces larger and sweeter fruits with vigorous seeds.

KEYWORDS: Camapu, nitrate, ammonium, germination.

\section{INTRODUCTION}

The Physalis genus is mainly characterized by its medicinal potential, but its fruits, with a typical inflated chalice around them (Tomassini et al. 2000), have a high nutritive value and are marketed in some countries. In Brazil, the planting and consumption of Physalis peruviana stands out, as its fruits can be used in the manufacture of sweets, jellies, juices, ice cream and yoghurts, being also consumed in natura and used in the making of sophisticated candies. Thus, in the north and northeast of the country, Physalis

\section{RESUMO}

Efeito de fontes nitrogenadas nas características dos frutos e qualidade fisiológica de sementes de Physalis angulata L.

A escolha da fonte nitrogenada adequada é de suma importância, pois afeta o desenvolvimento da planta e a produção de frutos e sementes. Objetivou-se avaliar a qualidade de frutos e sementes de Physalis angulata obtidos de plantas cultivadas em sistema hidropônico, sob concentrações de nitrato e amônio. Os tratamentos consistiram de quatro proporções de $\mathrm{NO}_{3}^{-}: \mathrm{NH}_{4}^{+}$ $(100: 0,75: 25,50: 50$ e 25:75). Ao final do cultivo, os frutos foram coletados para a realização de análises biométricas e químicas e para a retirada de sementes utilizadas no ensaio de germinação. O teste de germinação foi conduzido em câmara de germinação e os parâmetros avaliados foram a porcentagem, tempo médio, velocidade, coeficiente de uniformidade e frequência relativa. Os frutos de menor massa e diâmetro foram obtidos com doses acima de 50 \% de amônio; entretanto, houve aumento para ${ }^{\circ}$ Brix e relação sólidos solúveis/ acidez titulável. Essa dosagem também reduziu a porcentagem, velocidade e uniformidade de germinação. A utilização combinada das fontes nitrogenadas (50:50 de $\left.\mathrm{NO}_{3}^{-}: \mathrm{NH}_{4}^{+}\right)$é aconselhável, pois produz frutos maiores, mais doces e com sementes vigorosas.

PALAVRAS-CHAVE: Camapu, nitrato, amônio, germinação.

angulata L., a naturally occurring species (Matos 2000), appears as an alternative for the region.

P. angulata is a herbaceous plant of approximately $70 \mathrm{~cm}$ in height, popularly known in Brazil as mullaca, camapu and juá-de-capote (Freitas et al. 2006). Its fruit, a globose berry with numerous seeds, has a sweet and slightly acidic taste, with a high content of vitamins, phosphorus, iron, flavonoids and fibers (Velasquez et al. 2007, Rufato et al. 2008). Despite such a great potential, the species is not much explored, and little research is carried out on its cultivation, mainly regarding techniques to increase fruit quality and yield.

1. Received: Sep. 23, 2018. Accepted: Mar. 29, 2019. Published: Jun. 06, 2019. DOI: 10.1590/1983-40632019v4955074.

2. Universidade Estadual de Feira de Santana, Departamento de Ciências Biológicas, Feira de Santana, BA, Brasil. Email/ORCID: tamara.tanan@yahoo.com.br/0000-0002-3142-6632, alismarioagronomo@hotmail.com/0000-0001-7541-5292, lourivalpgneto@yahoo.com.br/0000-0002-9440-7949, marilzaagro@hotmail.com/0000-0003-3344-9106.

3. Universidade Federal do Recôncavo da Bahia, Centro de Ciências Agrárias, Ambientais e Biológicas, Cruz das Almas, BA, Brasil.Email/ORCID: uasley@gmail.com/0000-0001-6551-7746. 
Soil fertilization is directly related to crop yield, with nitrogen being the macronutrient most required by plants, as it influences photosynthesis, photoassimilates distribution between the reproductive and vegetative parts, cell growth and because it participates in the composition of important biomolecules (Queiroga et al. 2007). In addition, some studies on $P$. angulata fertilization have shown that increases in the use of NPK fertilizers result in reduced fruit weight and increased fruit losses (Thomé \& Osaki 2010, Tanan et al. 2013). Moreover, concerning the hydroponic cultivation of this species, Leite et al. (2017) observed an increase in fruit yield after adding higher nitrogen doses to the nutrient solution.

It is worth noting that plant growth is a stage with irreversible changes in the physical characteristics of the fruit, which are influenced by environmental factors such as temperature, solar radiation and rainfall, as well as genetic factors intrinsic to each plant material (Berilli et al. 2007). An important factor to consider is the nutritive status of the parent plant, as, during the fruit formation, nutrients reallocate from the plant parts to developing organs. Thus, it is necessary to adjust the fertilizer dose and determine the best nutrient source for each cultivated species.

Plants generally show different responses in their physiology and growth when submitted to different $\mathrm{N}$ sources. The preference for nitrate or ammonium varies depending on the species, what is generally related to genetic characteristics and environmental conditions (Majerowicz et al. 2000). Plants supplied with $\mathrm{N}-\mathrm{NH}_{4}^{+}$spend less ATP per assimilated nitrogen, but in excess it may cause toxicity problems (Kronzucker et al. 2001).

For the P. angulata species, the influence of nitrogen sources, mainly on fruit quality, has not been investigated. However, in tomato plants, combined applications of $\mathrm{NO}_{3}{ }^{-}$and $\mathrm{NH}_{4}^{+}$reduced the fruit yield in association with quality increase, bearing fruits with higher total soluble solids content, higher acidity and lower $\mathrm{pH}$ (Flores et al. 2003). Additionally, it is known that plants that grow under adequate nutritive conditions have a greater potential for producing well-formed and vigorous seeds (Alves et al. 2005). With the increasing demand for high quality seeds, the need to establish more adequate nutritive sources for seed production has also increased.

Thus, this study aimed to estimate the effect of nitrate and ammonium concentrations on the quality of $P$. angulata fruits and seeds obtained from plants grown in a nutrient solution.

\section{MATERIAL AND METHODS}

The experiment was carried out in Feira de Santana, Bahia state, Brazil (12 ${ }^{\circ} 14^{\prime} 21^{\prime \prime}$ S, 38 $38^{\circ} 58^{\prime} 46^{\prime \prime} \mathrm{W}$ and altitude of $258 \mathrm{~m}$ ), a dry sub-humid climate region, according to the Thornthwaite classification (Santos et al. 2016), in a greenhouse with transparent plastic cover, from November 2017 to March 2018.

Seeds were sown in polypropylene disposable cups $(200 \mathrm{~mL})$ containing commercial substrate and two seeds per cup. After germination, when the seedlings presented two pairs of true leaves with approximately $10 \mathrm{~cm}$, they were transplanted to a floating-bed hydroponic system. The reference nutrient solution used was Sarruge, modified for the cultivation of Physalis (Leite et al. 2017), composed of the following macronutrients: $\mathrm{N}=162 \mathrm{mg} \mathrm{L}^{-1}$; $\mathrm{P}=31 \mathrm{mg} \mathrm{L}^{-1} ; \mathrm{K}=234.6 \mathrm{mg} \mathrm{L}^{-1} ; \mathrm{Ca}=200.4 \mathrm{mg} \mathrm{L}^{-1}$; $\mathrm{Mg}=48.6 \mathrm{mg} \mathrm{L}^{-1} ; \mathrm{S}=64.1 \mathrm{mg} \mathrm{L}^{-1}$. The design was completely randomized, with 4 treatments and 5 replications composed of one plant each. The treatments $(\mathrm{T})$ consisted of nitrogen sources combinations in the nutrient solution, with four $\mathrm{NO}_{3}^{-}: \mathrm{NH}_{4}^{+}$ratios (T1 - 100:0; T2 - 75:25; T3 - 50:50; T4 - 25:75).

Vessels (6 L) containing one plant per pot were used. During cultivation, the $\mathrm{pH}$ of the nutrient solution was maintained between 5.5 and 6.5 , the electrical conductivity was monitored periodically and the solution was changed when the conductivity reduced by $25 \%$, when compared to the initial one.

At 73 days after planting, 50 fruits from each fully developed treatment were collected manually and randomly, from different positions in the plants, and taken to the laboratory. The physical characteristics evaluated were: fruit weight and seed weight per fruit, both determined using a precision analytical scale; fruit color, by comparison with the RHS colour chart (RHS 2001); transverse diameter (TD) (measured at the median region) and longitudinal diameter (LD) (measured from apex to base), using a digital caliper. Subsequently, the LD/ TD ratio was calculated to indicate the fruit shape.

The chemical characteristics evaluated were: soluble solids (SS) content, expressed in ${ }^{\circ}$ Brix and determined with a digital refractometer with temperature correction at $20^{\circ} \mathrm{C}$; and titratable acidity 
(TA), evaluated by titrimetry with a $0.1 \mathrm{~N} \mathrm{NaOH}$ solution (Moretti et al. 1998). Subsequently, the $\mathrm{SS} / \mathrm{TA}$ ratio was calculated.

The seeds were manually removed under running water until complete separation of the pulp, and allowed to dry at room temperature for $48 \mathrm{~h}$. Seed viability analysis was performed using a germination test, with four subsamples of 50 seeds, totaling 200 seeds per treatment. The seeds were placed for germination in Petri dishes with 2 germitest paper sheets moistened with distilled water. The experiments were conducted in a germination chamber with photoperiod of $12 \mathrm{~h}$ and alternating temperature of 20-30 ${ }^{\circ} \mathrm{C}$ (Souza 2009). The germinated seeds were counted daily for a period of 21 days, being considered germinated after the radicle emergence. The germination rate, mean germination time, germination speed and relative frequency were calculated with the obtained data.

The mean values of the obtained data were tested for normality by the Shapiro-Wilk test, and the data on fruit color and germination rate transformed by the arcsine of the square root of $\mathrm{X}$ over 100 for statistical analyses; however, the tables display values without transformation. The data were submitted to analysis of variance with the Tukey test at 0.05 of significance, using the Sisvar software (Ferreira 2014).

\section{RESULTS AND DISCUSSION}

The use of different nitrate and ammonium concentrations in the cultivation of $P$. angulata reflected on the quality of its fruits. Regarding the physical fruit characterization, a negative effect above $50 \%$ was observed due to the use of ammoniacal nitrogen in the nutrient solution, promoting a reduction in the fruit weight and cross-sectional and longitudinal diameters (Figures 1A, 1B and 1C).

The fruits with a greater weight $(1.89 \mathrm{~g})$ were obtained from plants grown only on $\mathrm{NO}_{3}^{-}$, while there was no significant difference for those on $50 \%$ of nitrate and $50 \%$ of ammonium. During the time that the ammonium prevailed in the hydroponic solution, the fruit mean weight was $1.07 \mathrm{~g}$ (Figure 1A). A similar result was observed in the study by Flores et al. (2003), in which the increase of ammonium reduced the tomato weight, being the highest value obtained with the addition of nitrate alone. On the other hand, Antúnez-Ocampo et al. (2014) observed no difference in the fruit weight of Physalis peruviana with the use of different nitrate and ammonium ratios; however, no doses higher than $50 \%$ of $\mathrm{NH}_{4}^{+}$were evaluated.

Similarly, the lowest values observed for the longitudinal and transverse diameters $(11.69 \mathrm{~mm}$ and $11.65 \mathrm{~mm}$, respectively) were for the $25: 75$ ratio of $\mathrm{NO}_{3}^{-}: \mathrm{NH}_{4}^{+}$, which also showed the lowest LD/TD ratio (Figures 1B, 1C and 1D). The longitudinal and transverse diameters, when analyzed together, define the fruit shape, being rounder the closer it is to 1 (Gerhardt et al. 1997). Thus, despite the reduction in the LD/TD ratio, the fruit shape did not change when different nitrogen sources were used, because it remained close to 1 , being considered as globular ovate fruits.

Rivera-Espejel et al. (2014) observed a similar result for tomatoes, obtaining fruits with the smallest longitudinal and transverse diameters when only the ammoniacal form was applied, and the highest values with the use of the combined forms, not exceeding $50 \%$ of ammonium. Their result was different from that described by Sokri et al. (2014), who did not observe differences in LD, TD, LD/TD and weight of apples grown under different nitrogen sources, corroborating the fact that the sensitivity to ammonia varies between species. Brito \& Kronzucker (2002) classified the Solanaceae family as sensitive to $\mathrm{NH}_{4}^{+}$, showing symptoms of toxicity such as severe reduction in growth.

The use of a higher proportion of ammonium in the hydroponic solution also reduced the seed weight per fruit, where treatments with ratios of 100:0, 75:25 and 50:50 of $\mathrm{NO}_{3}^{-}: \mathrm{NH}_{4}^{+}$obtained weights of $0.084 \mathrm{~g}, 0.095 \mathrm{~g}$ and $0.083 \mathrm{~g}$, respectively, whereas, in the 25:75 treatment, the weight was $0.043 \mathrm{~g}$ (Figure 1E). Ribeiro et al. (2002) found a correlation between fruit size and tomato seed yield, with larger fruits producing larger seed weights, what is in line with the data observed in the present study.

Regarding the fruit chemical characterization, there was also influence of the nitrogen source used. The soluble solids content was higher in the treatments with $50: 50$ and $25: 75$ of $\mathrm{NO}_{3}^{-}: \mathrm{NH}_{4}^{+}$, with $12.18^{\circ}$ Brix and $12.63^{\circ}$ Brix, respectively, indicating that the greater amount of ammonium in the solution the better it is for the accumulation of soluble solids (Figure 2A). Flores et al. (2003) and Rivera-Espejel et al. (2014) obtained similar results for tomatoes, and Antunez-Ocampo et al. (2014) for P. peruviana. 
Ammonium tends to reduce the absorption of cations by competition for absorption sites (Assunção et al. 2018), decreasing the concentration of calcium, magnesium and potassium (Serna et al. 1992). $\mathrm{K}$ is essential for increasing titratable acidity, and the use of $\mathrm{NH}_{4}^{+}$in the solution reduces
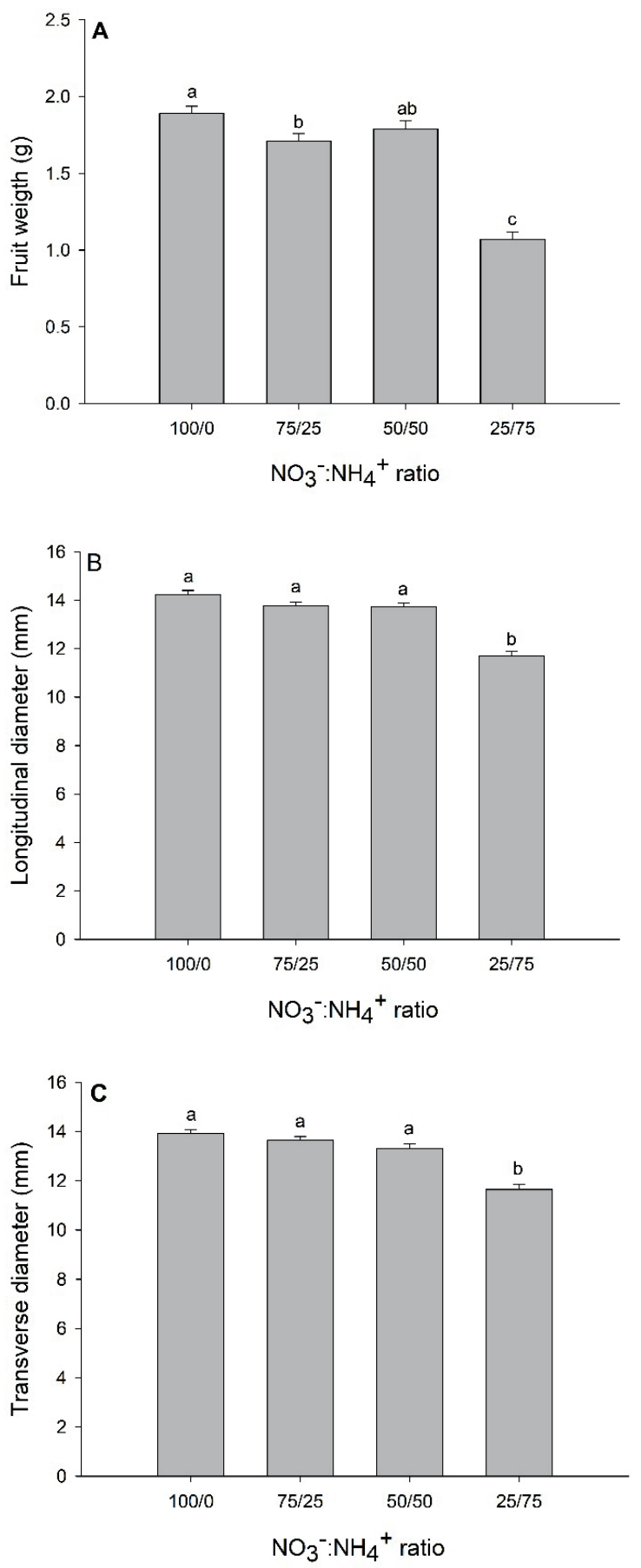

its concentration in apple and rice plants (Holzschuh et al. 2011, Sokri et al. 2014). Martínez et al. (2008) observed that one of the symptoms of K deficiency in P. peruviana plants was a $13.6 \%$ reduction in the soluble solids content.

The antagonistic action between $\mathrm{NH}_{4}^{+}$and other cations may also be related to the increase in fruit acidity (Sokri et al. 2014). For P. angulata fruits, the highest value of titratable acidity was observed using 75:25 of $\mathrm{NO}_{3}^{-}: \mathrm{NH}_{4}^{+}$, with no difference between treatments with only one nitrogen source in the solution (Figure 2B). Acidity is extremely important in industrialization, since it poses a greater difficulty of deterioration by microorganisms and allows a greater flexibility in the addition of sugar (Morgado et al. 2010).

Physalis is a climacteric fruit, i.e., after the fruit harvest, the respiratory rate increases due to the autocatalytic production of ethylene (Rufato et al.
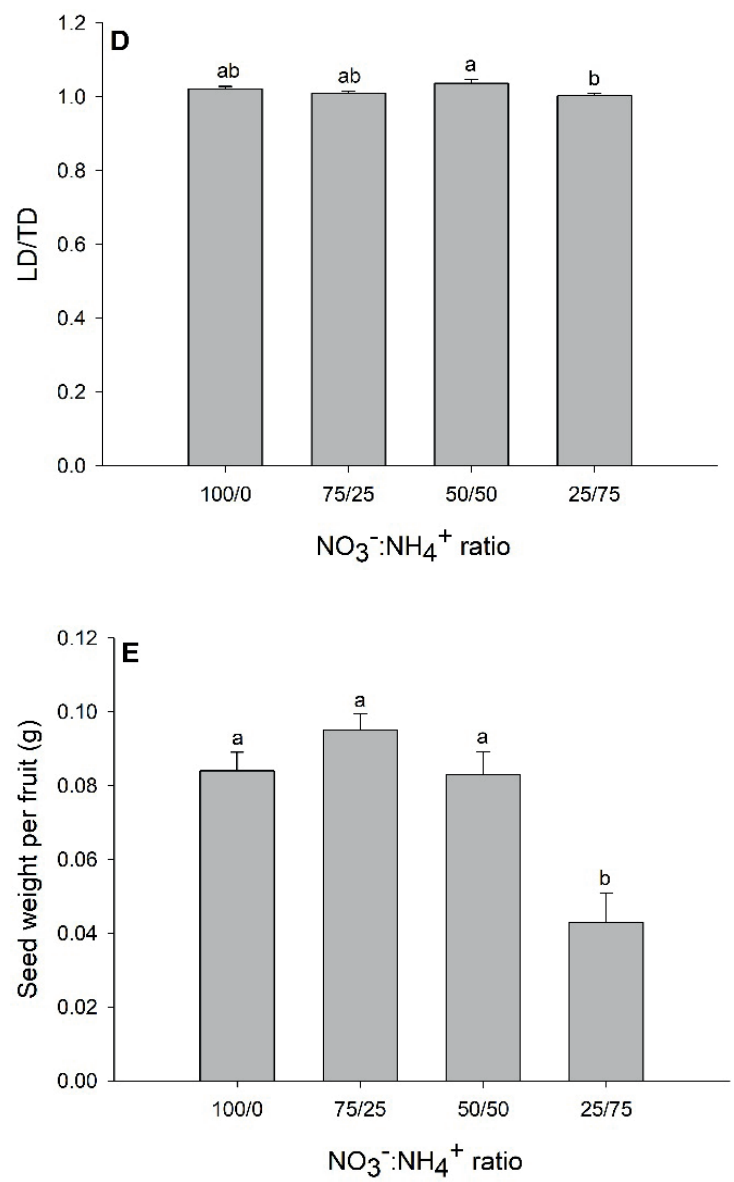

Figure 1. Physical characteristics of Physalis angulata fruits collected from plants grown under different nitrogen sources: A) fruit weight; B) longitudinal diameter (LD); C) transverse diameter (TD); D) LD/TD ratio; E) seed weight per fruit. * Different letters above the bars differ from each other by the Tukey test $(\mathrm{p}>0.05)$. 
2008), what induces some chemical changes in the fruit, such as alteration in the content of sugars and
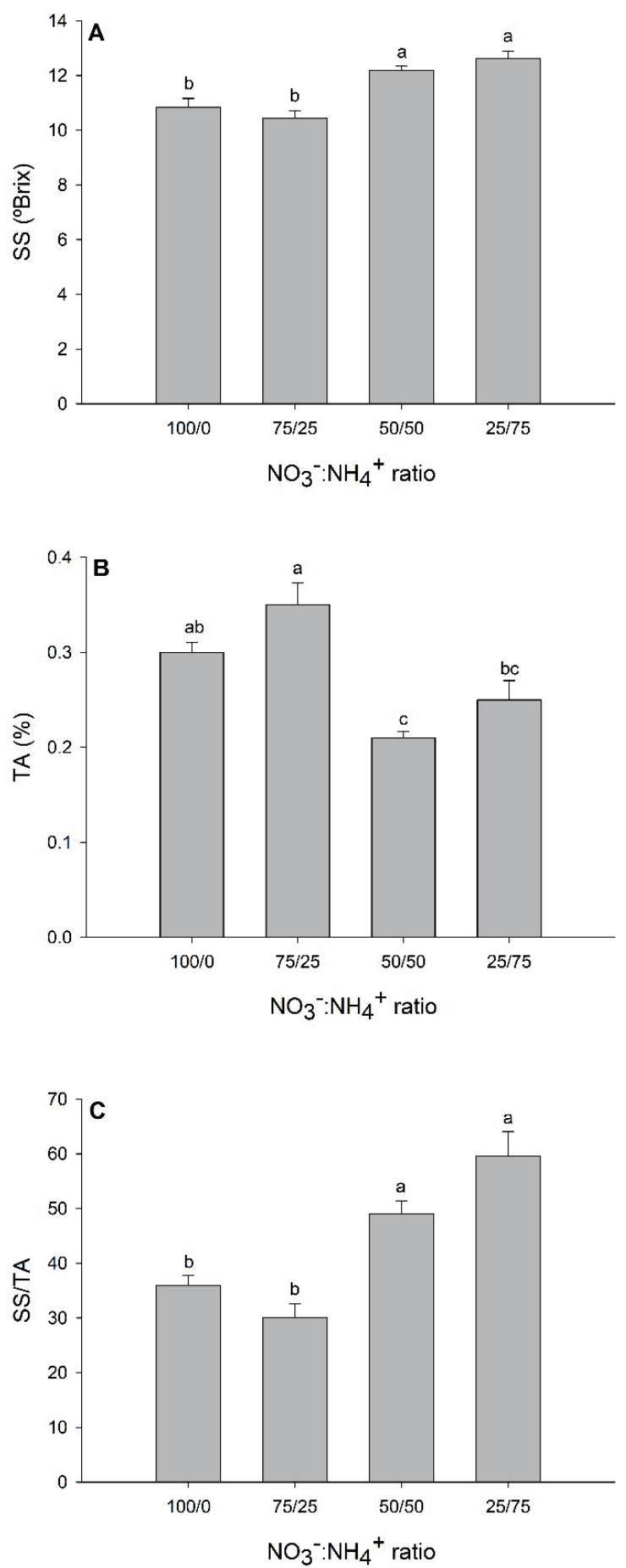

Figure 2. Chemical characterization of Physalis angulata fruits collected from plants grown under different nitrate and ammonium ratios: A) soluble solids (SS); B) titratable acidity (TA); C) SS/TA ratio. * Different letters above the bars differ from each other by the Tukey test $(\mathrm{p}>$ $0.05)$. acids. Thus, the analysis of the SS/TA ratio is more significant, because it provides a good evaluation of the fruit flavor. The use of different nitrate and ammonium ratios influenced this relationship, with the highest value of 59.51 obtained with the use of 25:75 of $\mathrm{NO}_{3}^{-}: \mathrm{NH}_{4}^{+}$, not differing from the 50:50 treatment (Figure 2C). According to Reis et al. (2015), a high SS and low TA indicate a high SS/TA ratio, what means a strong predominance of sweet flavor in fruits.

The correlation between high ammonium concentrations and ethylene evolution has been demonstrated in tomatoes (Barker \& Corey 1991, Feng \& Barker 2008), and it is known that ethylene alters the flavor of fleshy fruits, with changes in the relationships between acids and sugars. Fruit maturation increases the ACC-oxidase activity, ethylene production pathway from the methionine precursor. At high concentrations, ethylene regulates the enzymes activities that promote fruit modifications, such as softening, changes in color, increase in sugar content and reduction in acid content (Chitarra \& Chitarra 2005, Kerbauy 2008).

The acidity in fruits is attributed to the presence of organic acids, more often citric and malic acids. According to Chitarra \& Chitarra (2005), organic acids are dissolved in the vacuoles of the cells, both in free and combined forms, forming salts, esters and glycosides, and can be synthesized from sugars, oxidations, decarboxylation and carboxylation of other organic acids in the tricarboxylic acid pathway. During maturation, a decrease in the content of organic acids occurs in most fruits, since they are being widely used as substrates in the respiratory process. Thus, it was expected that the yellowest fruits (Table 1), characteristic color of maturation in $P$. angulata, presented lower titratable acidity. This was observed in the cultivation with 50:50 of $\mathrm{NO}_{3}^{-}: \mathrm{NH}_{4}^{+}$(Figure 2), what consequently produced sweeter fruits.

Table 1. Color of Physalis angulata fruits collected from plants grown under different nitrate and ammonium ratios.

\begin{tabular}{lrrrr}
\hline \multirow{2}{*}{ Fruit color (\%) } & \multicolumn{4}{c}{$\mathrm{NO}_{3}{ }^{-}: \mathrm{NH}_{4}{ }^{+}$ratio } \\
\cline { 2 - 5 } & $100: 0$ & $75: 25$ & $50: 50$ & $25: 75$ \\
\hline Greenish yellow & $88 \mathrm{a}$ & $64 \mathrm{~b}$ & $94 \mathrm{a}$ & $60 \mathrm{~b}$ \\
Green & $8 \mathrm{~b}$ & $36 \mathrm{a}$ & $6 \mathrm{~b}$ & $0 \mathrm{~b}$ \\
Dark green & $4 \mathrm{~b}$ & $0 \mathrm{~b}$ & $0 \mathrm{~b}$ & $40 \mathrm{a}$ \\
\hline * Different letters in the row differ from each other by the Tukey test $(\mathrm{p}<0.05)$.
\end{tabular}


The nitrogen source used also influenced fruit color, with a greater amount of dark green fruits in the treatment with the 25:75 ratio of $\mathrm{NO}_{3}^{-}: \mathrm{NH}_{4}^{+}$(Table 1). According to Galvis et al. (2005), the change in color of Physalis fruits indicates maturation, changing from dark green to yellow. Usually, with the evolution of tissue maturation, there is a degradation of chlorophyll, making visible pre-existing pigments and synthesis of new pigments responsible for the color of each species (Chitarra \& Chitarra 2005). Thus, the highest rate of dark green fruits observed with the use of $75 \%$ of ammonium in the solution indicates that they have not yet reached the maturation stage, what may be related to the delay of more than one week for the start of fruit bearing in that treatment (data not shown). Ben-Oliel et al. (2004) observed that ammonium extended the period for the development of tomato fruits and delayed harvest in one week.

Despite the delay in the ripening of fruits when using the 27:75 ratio of $\mathrm{NO}_{3}^{-}: \mathrm{NH}_{4}^{+}$, these fruits presented a low titratable acidity, what is not common in immature fruits. This may be related to the nitrogen and carbon balance in the plant. Because it is toxic to the plant, ammonium needs to be readily assimilated through the GS and GOGAT enzymes, requiring a large amount of carbon skeletons (Taiz \& Zeiger 2017). The reduction in the organic acid concentration and amino acid accumulation is a response to high ammonium concentrations in the medium (Brito \& Kronzucker 2002). Considering that most organic acids are translocated from roots or leaves to fruits (Chitarra \& Chitarra 2005), the low concentration of these acids in the plant will affect their accumulation at the start of fruit formation. In addition, Scheible et al. (1997) demonstrated that nitrate has a role in the carbon metabolism, initiating a coordinated increase in the genes expression involved in the synthesis of organic acids. Therefore, plants cultivated with predominance of nitrate in the medium tend to have a higher acidity.

The fruit maturity degree at harvest may influence the physiological quality of the seed, what was observed with the lowest germination rate obtained in the treatment with the 25:75 ratio of $\mathrm{NO}_{3}^{-}: \mathrm{NH}_{4}^{+}$. Seeds extracted from fruits of plants grown with up to $50 \%$ of ammonium in the solution had a high germination rate, higher than $95 \%$ (Table 2).

The reduction observed with the use of 25:75 of $\mathrm{NO}_{3}^{-}: \mathrm{NH}_{4}^{+}$may be related to the competition of
Table 2. Germination rate $(\mathrm{G})$, mean germination time (MGT) and mean speed (S) of seed germination of Physalis angulata fruits from different nitrogen sources.

\begin{tabular}{lrrrr}
\hline Germination & \multicolumn{4}{c}{$\mathrm{NO}_{3}^{-}: \mathrm{NH}_{4}^{+}$ratio } \\
\cline { 2 - 5 } analyzes & $100: 0$ & \multicolumn{1}{c}{$75: 25$} & $50: 50$ & \multicolumn{1}{c}{$25: 75$} \\
\hline $\mathrm{G}(\%)$ & $99.00 \mathrm{a}$ & $99.50 \mathrm{a}$ & $100.00 \mathrm{a}$ & $86.00 \mathrm{~b}$ \\
MGT $\left(\right.$ day $\left.^{-1}\right)$ & $3.60 \mathrm{~b}$ & $3.06 \mathrm{~b}$ & $3.27 \mathrm{~b}$ & $4.78 \mathrm{a}$ \\
$\mathrm{S}\left(\right.$ day $\left.^{-1}\right)$ & $0.27 \mathrm{~b}$ & $0.32 \mathrm{a}$ & $0.30 \mathrm{ab}$ & $0.21 \mathrm{c}$ \\
\hline
\end{tabular}

* Different letters in the row differ from each other by the Tukey test $(\mathrm{p}<0.05)$.

$\mathrm{NH}_{4}^{+}$and other cations for absorption sites, such as $\mathrm{Ca}_{2}^{+}$, which has its absorption and, consequently, its content reduced at high concentrations of ammonium (Serna et al. 1992). Calcium is positively related to germination, acting to maintain the integrity of cell membranes, what apparently gives the seeds a higher physiological quality (Peske et al. 2003). However, Oliveira et al. (2003) obtained a different result for bean, which, in the treatment with ammonium sulphate, provided a higher germination rate, if compared to that of potassium nitrate; but they evaluated seeds from a field crop rather than using a hydroponic system.

In addition to reducing the germination rate, the predominant use of the ammoniacal form in the nutrient solution increased the mean germination time. For the ratios 100:0, 75:25 and 50:50, the mean germination times were $3.6,3.0$ and 3.2 days, very close to that described by Souza et al. (2017), who reported a mean time of 3.8 days. The highest germination speed was observed in the treatments with 75:25 and 50:50 of $\mathrm{NO}_{3}^{-}: \mathrm{NH}_{4}^{+}$, indicating that the application of nitrogenous forms, not exceeding $50 \%$ of ammonium during cultivation, generated more vigorous seeds (Table 2).

Many factors are involved in seed composition and vigor, with vigor being the sum of all properties that determine the potential for rapid and uniform emergence and development of normal seedlings (Marcos Filho 2015). The highest germination uniformity rate was observed in the treatments with 100:0, 75:25 and 50:50 of $\mathrm{NO}_{3}^{-}: \mathrm{NH}_{4}^{+}$(Figure 3), which were unimodal with the application of such ratios, differently from the treatment with $75 \%$ of ammonium, which was polymodal.

From fertilization, the egg evolves undergoing modifications that, as a final result, originate the mature seed, with maximum size, dry weight and vigor (Peske et al. 2003). This occurs due to the 


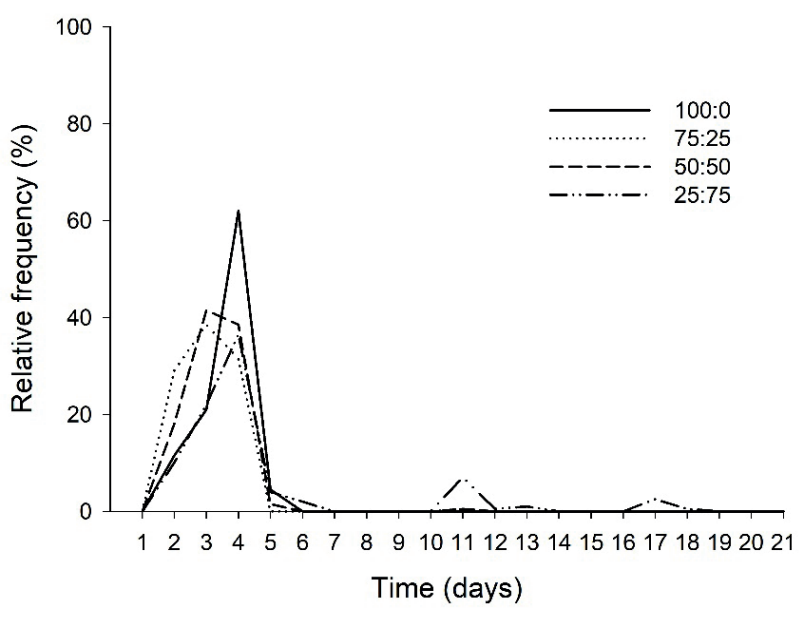

Figure 3. Relative frequency of germination of Physalis angulata seeds collected from fruits from different nitrate and ammonium ratios.

accumulation of photoassimilates in the seed. Thus, changes in the photosynthetic apparatus may influence its formation. Lewis et al. (1989) reported that the negative effect of $\mathrm{NH}_{4}^{+}$has been attributed to the need to use carbohydrates primarily for the rapid assimilation of absorbed ammonium, due to its toxicity, to the detriment of other plant activities, as observed by Silva et al. (2018), in which P. angulata reduced the dry weight increase at high doses of $\mathrm{NH}_{4}^{+}$. Therefore, the reduction in the carbon availability for synthesis of seed reserves may compromise its germinability and vigor.

Furthermore, the obtained results indicate that the predominance of ammonium in the nutrient solution leads to ionic imbalance, compromising the absorption of other essential cations for the plant, reflecting on fruits with a greener color, smaller and with seeds showing lower germination and vigor rates. Several authors have observed a better development of plants and quality of fruits and grains with the combination of those two nitrogen sources (Marinho et al. 2001, Ben-Oliel et al. 2004, Holzschuh et al. 2011, Antunez-Ocampo et al. 2014, Rivera-Espejel et al. 2014, Sun et al. 2014), thus confirming the results for $P$. angulata found in the present study.

\section{CONCLUSIONS}

1. High concentrations of ammonium in the nutrient solution compromise the fruit size, but increase the soluble solids/titratable acidity ratio;
2. The combined use of nitrogen sources (50:50 of $\mathrm{NO}_{3}^{-}: \mathrm{NH}_{4}^{+}$) is recommended, because it produces larger and sweeter fruits, with vigorous seeds.

\section{REFERENCES}

ALVES, E. U. et al. Rendimento e qualidade fisiológica de sementes de coentro cultivado com adubação orgânica e mineral. Revista Brasileira de Sementes, v. 27, n. 1, p. 132-137, 2005.

ANTÚNEZ-OCAMPO, O. M. et al. Aplicación de amônio y nitrato en plantas de Physalis peruviana L. Agrociencia, v. 48, n. 8, p. 805-817, 2014.

ASSUNÇÃO, N. S. et al. Nutritional quality of tomatoes as a function of nitrogen sources and doses. African Journal of Agricultural Research, v. 13, n. 19, p. 9961000, 2018.

BARKER, A. V.; COREY, K. A. Interrelations of ammonium toxicity and ethylene action in tomato. HortScience, v. 26, n. 2, p. 177-180, 1991.

BEN-OLIEL, G. et al. Effects of ammonium to nitrate ratio and salinity on yield and fruit quality of large and small tomato fruit hybrids. Journal of Plant Nutrition, v. 27, n. 10, p. 1795-1812, 2004.

BERILLI, S. da S. et al. Avaliação da taxa de crescimento de frutos de mamão (Carica papaya L.) em função das épocas do ano e graus-dias acumulados. Revista Brasileira de Fruticultura, v. 29, n. 1, p. 11-14, 2007.

BRITO, D. T.; KRONZUCKER, H. J. $\mathrm{NH}_{4}^{+}$toxicity in higher plants: a critical review. Journal of Plant Physiology, v. 159, n. 6, p. 567-584, 2002.

CHITARRA, M. I. F.; CHITARRA, A. B. Pós-colheita de frutos e hortaliças: fisiologia e manuseio. 2. ed. Lavras: Ed. UFLa, 2005.

FENG, J.; BARKER, A. V. Ethylene evolution and ammonium accumulation by tomato plants under water and salinity stresses: part II. Journal of Plant Nutrition, v. 15, n. 11, p. 2471-2490, 2008.

FERREIRA, D. F. Sisvar: a guide for its bootstrap procedures in multiple comparisons. Ciência e Agrotecnologia, v. 38, n. 2, p. 109-112, 2014.

FLORES, P. et al. Tomato yield and quality as affected by nitrogen source and salinity. Agronomie, v. 23, n. 3, p. 249-256, 2003.

FREITAS, T. A.; RODRIGUES, A. C. C.; OSUNA, J. T. A. Cultivation of Physalis angulata L. and Anadenanthera colubrina [(Vell.) Brenan] species of the Brazilian semiarid. Revista Brasileira de Plantas Medicinais, v. 8, special issue, p. 201-204, 2006. 
GALVIS, J. A.; FISCHER, G.; GORDILLO, M. Cosecha e poscosecha de la uchuva. In: FLÓREZ RONCANCIO, V.; FISCHER, G.; SORA, A. D. Producción, poscosecha y exportación de la uchuva (Physalis peruviana L.). Bogotá: Universidad Nacional de Colombia, 2005. p. 165-188.

GERHARDT, L. B. A. et al. Características físicoquímicas dos frutos de quatro cultivares e três clones de goiabeira em Porto Lucena, RS. Pesquisa Agropecuária Brasileira, v. 32, n. 2, p. 185-192, 1997.

HOLZSCHUH, M. J. et al. Absorção de nutrientes e crescimento do arroz com suprimento combinado de amônio e nitrato. Revista Brasileira de Ciências do Solo, v. 35, n. 4, p. 1357-1366, 2011.

KERBAUY, G. B. Fisiologia vegetal. 2. ed. Rio de Janeiro: Guanabara Koogan, 2008.

KRONZUCKER, H. J. et al. Ammonium toxicity and the real cost of transport. Trends in Plant Science, v. 6, n. 8, p. 335-337, 2001.

LEITE, R. S. et al. Hydroponic cultivation of Physalis angulata $\mathrm{L}$.: growth and production under nitrogen doses. Pesquisa Agropecuária Tropical, v. 47, n. 2, p. 145-151, 2017.

LEWIS, O. A. M. et al. Effect of nitrogen source on growth response to salinity stress in maize and wheat. New Phytologist, v. 111, n. 2, p. 155-160, 1989.

MAJEROWICZ, N. et al. Growth and nitrogen metabolism of Catasetum fimbriatum (Orchidaceae) grown with different nitrogen sources. Environmental and Experimental Botany, v. 44, n. 3, p. 195-206, 2000.

MARCOS FILHO, J. Seed vigor testing: an overview of the past, present and future perspective. Scientia Agricola, v. 72, n. 4, p. 363-374, 2015.

MARINHO, C. S. et al. Doses de nitrogênio e a qualidade dos frutos do mamoeiro. Scientia Agricola, v. 58, n. 2, p. 345-348, 2001.

MARTÍNEZ, F. E. et al. Efecto de la deficiencia de N, P, K, $\mathrm{Ca}, \mathrm{Mg}$ y $\mathrm{B}$ en componentes de producción y calidad de la uchuva (Physalis peruviana L.). Agronomia Colombiana, v. 26, n. 3, p. 389-398, 2008.

MATOS, F. J. A. Plantas medicinais: guia de seleção e emprego de plantas usadas em fitoterapia no nordeste do Brasil. 2. ed. Fortaleza: Ed. UFC, 2000.

MORETTI, C. L. et al. Chemical composition and physical properties of pericarp, locule and placental tissues of tomatoes with internal bruising. Journal of the American Society for Horticultural Science, v. 123, n. 4, p. 656-660, 1998.

MORGADO, M. A. D. et al. Correlações fenotípicas em características fisicoquímicas do maracujazeiro-azedo. Acta Agronómica, v. 59, n. 4, p. 457-461, 2010.
OLIVEIRA, A. P. et al. Produção e qualidade fisiológica de sementes de feijão-vagem em função de fontes e doses de nitrogênio. Revista Brasileira de Sementes, v. 25, n. 1, p. 49-55, 2003.

PESKE, S. T.; ROSENTHAL, M. D.; ROTA, G. R. M. Sementes: fundamentos científicos e tecnológicos. Pelotas: Ed. UFPel, 2003.

QUEIROGA, R. C. F. et al. Influência de doses de nitrogênio na produtividade e qualidade do melão Cantalu pensis sob ambiente protegido. Horticultura Brasileira, v. 25 , n. 4 , p. 550-556, 2007.

REIS, D. R. D. et al. Caracterização biométrica e físicoquímica de pimenta variedade biquinho. Enciclopédia Biosfera, v. 11, n. 21, p. 454, 2015.

RIBEIRO, F. P. et al. Correlação entre produção de sementes e tamanho de frutos de tomate, variedade Fanny grupo salada. Horticultura Brasileira, v. 20, n. 2, p. 403, 2002.

RIVERA-ESPEJEL, E. A. et al. Fertilización de tomate con nitrato y amonio en raíces separadas en hidroponía. Revista Chapingo Série Horticultura, v. 20, n. 1, p. 5770, 2014.

RUFATO, L. et al. Aspectos técnicos da cultura da Physalis. Lages: Ed. Udesc, 2008.

SANTOS, R.A.; MARTINS, D. L.; SANTOS, R. L. Balanço hídrico e classificação climática de Thornthwaite em Feira de Santana, Bahia. In: SIMPÓSIO BRASILEIRO DE CLIMATOLOGIA GEOGRÁFICA, 12., 2016, Goiânia. Anais... Goiânia: Ed. UFG, 2016. p. 1889-1900.

SCHEIBLE, W-R. et al. Nitrate acts as a signal to induce organic acid metabolism and repress starch metabolism in tobacco. The Plant Cell, v. 9, n. 5, p. 783-789, 1997.

SERNA, M. D. et al. The influence of nitrogen concentration and ammonium/nitrate ratio on $\mathrm{N}$-uptake, mineral composition and yield of citrus. Plant and Soil, v. 147, n. 1, p. 13-23, 1992.

SILVA, A. L. et al. Rendimento de massa seca de Physalis angulata $\mathrm{L}$. sob proporções de nitrato e amônio em cultivo hidropônico. Enciclopédia Biosfera, v. 15, n. 27, p. 31-38, 2018

SOKRI, S. M. et al. Fruit quality and nitrogen, potassium, and calcium content of apple as influenced by nitrate:ammonium ratios in tree nutrition. Journal of Plant Nutrition, v. 38, n. 10, p. 1-19, 2014.

SOUZA, C. L. M. et al. Biometric characteristics of fruits and physiological characterization of seeds of Physalis species (Solanaceae). Agrária, v. 12, n. 3, p. 277-282, 2017. 
SOUZA, C. L. M. Germinabilidade de sementes de Physalis angulata L. (Solanaceae) sob condições de estresses abióticos. 2009. 70 f. Dissertação (Mestrado em Recursos Genéticos Vegetais) - Universidade Estadual de Feira de Santana, Feira de Santana, 2009.

SUN, Y. D.; LUO, W. R.; LIU, H. C. Effects of different nitrogen forms on the nutritional quality and physiological characteristics of Chinese chive seedlings. Plant Soil and Environment, v. 60, n. 5, p. 2016-220, 2014.

TAIZ, L. et al. Fisiologia e desenvolvimento vegetal. 6. ed. Porto Alegre: Artmed, 2017.

TANAN, T. T. et al. Physalis angulata L. cultivada sob níveis de adubação NPK. Magistra, v. 25, n. esp., p. 378379, 2013.
THE ROYAL HORTICULTURAL SOCIETY (RHS). RHS colour chart. London: RHS, 2001.

THOMÉ, M.; OSAKI, F. Adubação de nitrogênio, fósforo e potássio no rendimento de Physalis spp. Revista Acadêmica: Ciências Agrárias e Ambientais, v. 8, n. 1, p. 11-18, 2010.

TOMASSINI, T. C. B. et al. Gênero Physalis: uma revisão sobre vitaesteroides. Química Nova, v. 23. n. 1, p. 47-57, 2000.

VELASQUEZ, H. J. C. et al. Estudio preliminar de la resistencia mecânica a la fractura y fuerza de firmeza para fruta de uchuva (Physalis peruviana L.). Revista de la Facultad Nacional de Agronomía, v. 60, n. 1, p. 37853796, 2007. 